\title{
Sprawozdanie z ogólnopolskiej konferencji naukowej pt. Praca organiczna: osoby, miejsca, procesy, Poznań, 13-14 X 2020 r.
}

Polscy pozytywiści uważali, że społeczeństwo przypomina żywy organizm, a do jego prawidłowego funkcjonowania niezbędne jest zdrowie wszystkich organów. Dla społeczeństwa może to oznaczać, że aby właściwie funkcjonowało, potrzebny jest rozwój wszystkich jego warstw i dziedzin życia. Po rozbiorach, kiedy ziemie polskie trafily pod okupację austriacką, pruską i rosyjską, praca organiczna zaczęła stanowić coraz większą wartość. Najwcześniej rozpoczęła się w Wielkim Księstwie Poznańskim, a jednymi z jej prekursorów byli Dezydery Chłapowski i Karol Marcinkowski. Wśród towarzystw, które powstały w tym okresie, mających na celu szerzenie pracy organicznej były między innymi Spółka Akcyjna Bazar czy Poznańskie Towarzystwo Przyjaciół Nauk. W gmachu tego ostatniego w dniach 13-14 X 2020 r. odbyła się ogólnopolska konferencja naukowa przedstawiająca wyniki najnowszych badań nad aspektami pracy organicznej i ukazująca nowoczesne promowanie jej idei.

Zorganizowanie konferencji w formie tradycyjnej uniemożliwiła szalejąca na całym świecie epidemia COVID-19. Obrady przeniesiono na system zdalny, aby nie narażać uczestników. Organizatorem konferencji było Poznańskie Towarzystwo Przyjaciół Nauk, a patronat honorowy nad wydarzeniem objął Prezydent Miasta Poznania Jacek Jaśkowiak oraz Marszałek Województwa Wielkopolskiego Marek Woźniak.

Konferencję otworzył były prezes PTPN oraz jeden z pomysłodawców wydarzenia, prof. UAM dr hab. Andrzej Gulczyński. Pierwszy wystąpił prof. UAM dr hab. Przemysław Matusik (Uniwersytet im. Adama Mickiewicza w Poznaniu), który opowiedział o początkach pracy organicznej w Poznaniu (Poznańskie początki programu pracy organicznej). Następnie prof. UKW dr hab. Maciej Gloger (Uniwersytet Kazimierza Wielkiego w Bydgoszczy) skupił się na filozofii organicyzmu w Polsce (Filozoficzne źródła dziewiętnastowiecznego organicyzmu w Polsce). O ludziach i in- 
stytucjach w zachodniej Wielkopolsce parających się pracą organiczną do wybuchu II wojny światowej (Instytucje i ludzie pracy organicznej w zachodniej Wielkopolsce do 1939 roku) rozważał z kolei prof. UZ dr hab. Tomasz Nodzyński (Uniwersytet Zielonogórski).

Po krótkiej przerwie rozpoczęto drugą część konferencji, a pierwszy wykład wygłosił prof. IH PAN dr hab. Tomasz Krzemiński (Instytut Historii im. Tadeusza Manteuffla Polskiej Akademii Nauk), który skoncentrował się na pracy organicznej na Pomorzu (Praca organiczna na Pomorzu w XIX wieku. Uwarunkowania - ludzie - powiązania międzydzielnicowe). Prof. UMCS dr hab. Mariusz Korzeniowski (Uniwersytet Marii Curie-Skłodowskiej w Lublinie) przedstawił z kolei postawę Polaków mieszkających na Kresach Wschodnich wobec organicyzmu (Polacy ukrainni wobec idei pracy organicznej w latach 1864-1914). Następny wykład został poświęcony Galicji w okresie jej autonomii i idei pracy organicznej na tym terenie (Idea pracy organicznej $w$ Galicji okresu autonomii), a jego autorem był dr Mariusz Menz (UAM). Drugą część konferencji, a jednocześnie pierwszy dzień tego wydarzenia, zamknęło wystąpienie wspomnianego już prof. UAM dr. hab. Andrzeja Gulczyńskiego (UAM), który zapoznał uczestników z planami wydawniczymi związanymi z pracą organiczną (Praca organiczna: od encyklopedii do Encyklopedii).

Drugi dzień konferencji rozpoczął panel dyskusyjny poświęcony powstaniu Wielkopolskiego Szlaku Pracy Organicznej. Swoje koncepcje autorskie zaprezentowali przedstawiciele czterech instytucji naukowych: Gnieźnieńskiej Szkoły Wyższej Milenium (prof. GSW dr hab. Armin Mikos von Rohrscheidt), UAM (Dawid Abramowicz), Uniwersytet Ekonomiczny w Poznaniu (prof. UEP dr hab. Agnieszka Ziomek) oraz zespół badaczy z PTPN (prof. UEP dr hab. Agnieszka Niezgoda, prof. UAM dr hab. Alina Zajadacz, prof. UEP dr hab. Filip Kaczmarek i prof. UAM dr hab. Andrzej Gulczyński). O samym zaś programie stworzenia szlaku i pracach z nim związanych opowiedział dyrektor Departamentu Kultury Urzędu Marszałkowskiego, Włodzimierz Mazurkiewicz.

Po panelu dyskusyjnym przyszedł czas na kolejne referaty, które tego dnia były realizowane w czterech osobnych panelach. Pierwszy z nich otworzył referat $\mathrm{dr}$ Anny Kryszak (PTPN), która przybliżyła uczestnikom postać pierwszego prezesa PTPN Augusta Cieszkowskiego i jego wkład w rozwój pracy organicznej („Można i wodę z ogniem złaczyć..., ale... trzeba machinę parowa pierw zbudować). O kolejnym prezesie PTPN, Tytusie Działyńskim, jak również o początkach tej instytucji (Tytus Działyński i początki Poznańskiego Towarzystwa Przyjaciót Nauk) opowiedział dyrektor Biblioteki dr Norbert Delestowicz (PTPN). Panel zamknęło wystąpienie 
Agnieszki Murawskiej (Muzeum Narodowe w Poznaniu), która skupiła się na postaci Seweryna Mielżyńskiego („Zebrać w jeden snop kłosy... rozrzucone”. Rzecz o Sewerynie Mielżyńskim jako organiczniku).

Po krótkiej przerwie mieliśmy możliwość wysłuchać dwóch referatów. Pierwszy z nich oscylował wokół pracy organicznej połączonej z walką z germanizacją na ziemiach polskich (W pracy organicznej i walce z germanizacją. Hr. Józef Czarnecki oraz dobrzyccy księża społecznicy: ks. Stanistaw Nizieński i ks. Stanistaw Śniatała na przełomie XIX i XX w.), a jego autorem był dr Stanisław Borowiak (Muzeum Ziemiaństwa w Dobrzycy). Z kolei Alina Kucharska (PTPN) mówiła o dziale ludoznawczym w PTPN oraz o kulturze ludowej ( $W$ trosce o polska kulturę ludowa. Dziat Ludoznawczy Towarzystwa Przyjaciół Nauk).

Trzeci panel otworzył referat Adriana Talarka (Uniwersytet Humanistyczno-Przyrodniczy im. Jana Długosza w Częstochowie), który przeanalizował pracę organiczną $\mathrm{w}$ rejonie częstochowskim (Praca organiczna $w$ rejonie częstochowskim po powstaniu styczniowym). Następnie o działalności religijnej i próbie jednania ludzi i instytucji w pracy (Między idea a czynem. Jednanie ludzi i instytucji w pracy na rzecz magdalenek, sierot $i$ chorych, na przykładzie działalności Zgromadzenia Sióstr Opatrzności Bożej) rozprawiała dr Elżbieta s. Monika Albiniak CSDP. Trzeci referat zwrócił uwagę na kolejne pokolenie organiczników i jednego z jego głównych przedstawicieli, Cyryla Ratajskiego („Człowiek nieugiętej pracy”. Cyryl Ratajski [1875-1942] jako przedstawiciel kolejnego pokolenia organiczników), a jego autorką była Maria Niestrawska (Biblioteka Raczyńskich w Poznaniu).

Ostatni panel, zamykający jednocześnie całą konferencję, otworzył dr Mariusz Niestrawski (Muzeum Narodowe Rolnictwa i Przemysłu Rolno-Spożywczego w Szreniawie), a jego wystąpienie dotyczyło upamiętnienia organiczników w Muzeum w Szreniawie (Upamiętnienie ikon wielkopolskiej pracy organicznej w Muzeum Narodowym Rolnictwa i Przemystu Rolno-Spożywczego). Następnie Dominik Górny (Towarzystwo im. Hipolita Cegielskiego) opowiedział o praktycznym wyborze budowania jakości życia, jaki niosła ze sobą praca organiczna (Praca organiczna praktyczny wymiar budowania jakości życia obywatelskiego). Na zakończenie dr Marek Przybylski (Fundacja Zakłady Kórnickie) zainteresował uczestników działaniami Fundacji Zakłady Kórnickie w kontekście pracy organicznej (Recepcja pracy organicznej na przykładzie działań FZK).

Uroczystego zamknięcia i podsumowania konferencji dokonał prezes PTPN, prof. UEP dr hab. Filip Kaczmarek, który podziękował wszystkim uczestnikom za udział w wydarzeniu, zwłaszcza w tak trudnym dla wszystkich czasie. Prof. Kaczma- 
rek zwrócił również uwagę na to, że nie jest to pierwsza konferencja organizowana online i zapewne nie ostatnia. Wyraził też zadowolenie, że mimo przeciwności, jakie niesie ze sobą epidemia, naukowcy, członkowie towarzystw i pracownicy instytucji kultury są gotowi na merytoryczną wymianę zdań na nurtujący ich temat, w tym wypadku bardzo ważnej dla Wielkopolski pracy organicznej.

Nadesłane: 4 XI 2020

Zaakceptowane: 6 XI 2020

mgr Jakub Wojtczak

Uniwersytet im. Adama Mickiewicza w Poznaniu Wydział Historii

ul. Uniwersytetu Poznańskiego 7

61-614 Poznań

e-mail:kub.wojtczak@gmail.com 